\title{
Synotis xinningensis (Asteraceae), a new species from Hunan, China
}

\author{
Ming Tang ${ }^{1,3}$, Long-Yuan Wang ${ }^{2}$ and Qin-Er Yang ${ }^{1 *}$
}

\begin{abstract}
Background: Synotis is one of the several genera within Senecioneae (Asteraceae) with more than 40 species that are mainly distributed in China or in the Sino-Himalayan region. During a botanical expedition in central and southwestern China in 2011, we found an unusual population of Synotis in southwestern Hunan Province. To determine the taxonomic identity of the population, we carried out gross-morphological, floral micromorphological, and cytological observations.

Results: Our gross-morphological observations have shown that the population is most similar to Synotis changiana Y. L. Chen, but readily distinguishable in the discoid capitula (vs. radiate), and in the bracts of calyculus 9-10 (vs. 6-8), 6-7 mm long (vs. 3-4 mm). The floral micromorphological observations on the population and S. changiana agree with previous reports for other species of Synotis. The chromosomes of the population are counted to be $2 n=40+0-1$ B. Its karyotype is formulated as $2 n=22 m+14 s m+4 s t$.

Conclusions: The population is determined to represent a new species, i.e. Synotis xinningensis M. Tang \& $\mathrm{Q}$. E. Yang, which is described herein. The new species belongs to Synotis ser. Synotis.
\end{abstract}

Keywords: Asteraceae; Chromosome number; Karyotype; Senecioneae; Synotis xinningensis

\section{Background}

Within Senecioneae (Asteraceae), there are several genera with more than 40 species that are mainly in China or in the Sino-Himalayan region. They include Cremanthodium Benth., Ligularia Cass., Parasenecio W. W. Smith \& Small, Sinosenecio B. Nord., and Synotis (C. B. Clarke) C. Jeffrey \& Y. L. Chen (Jeffrey and Chen 1984; Chen et al. 2011). One of us (Yang) and colleagues have a strong interest in these genera and are carrying out in-depth systematic studies of them. These studies have focused on Sinosenecio (e.g., Liu and Yang 2010, 2011a, b, c, d, 2012; Liu et al. 2009, 2010, 2011; Zhang et al. 2008) and have made important contributions to our knowledge of the genus (Nordenstam and Pelser 2011). The genus now under study is Synotis.

Synotis is a genus of about 54 species, all endemic to the Sino-Himalayan region except for S. atractylidifolia (Y. Ling) C. Jeffrey \& Y. L. Chen, which occurs in northern

\footnotetext{
* Correspondence: qeyang@scib.ac.cn

${ }^{1}$ Key Laboratory of Plant Resources Conservation and Sustainable Utilization, South China Botanical Garden, Chinese Academy of Sciences, Xingke Road, Tianhe District, Guangzhou 510650, China

Full list of author information is available at the end of the article
}

China (Jeffrey and Chen 1984; Chen 1999; Nordenstam 2007; Chen et al. 2011). Chen (1999) and Chen et al. (2011) recorded 43 species of Synotis in China.

During a botanical expedition in central and southwestern China in 2011, we found an unusual population of Synotis on Lang Shan, Xinning County, in southwestern Hunan Province. The plants were most similar to S. changiana Y. L. Chen, a species described from Guangxi (Chen 1995), but very readily distinguishable in the discoid capitula. Further examination revealed additional differences in the number and length of the bracts of calyculus. We determined that the population represents an undescribed species, i.e. Synotis xinningensis $\mathrm{M}$. Tang \& Q. E. Yang, which is here described. In 2012, we found two additional gatherings of the new species in the Herbarium of the Institute of Botany, Chinese Academy of Sciences (PE).

\section{Methods}

Floral micromorphological character observations

For observation of the filament collar and anther endothecial cell wall thickenings of Synotis xinningensis (voucher: Long-yuan Wang \& Ming Tang 123, HAST, 
IBSC) and its putative closest relative, S. changiana (voucher: Long-yuan Wang \& Ming Tang 111, HAST, IBSC), heads were boiled in distilled water for $3 \mathrm{~min}$, and then fixed in Carnoy's solution (glacial acetic acid: absolute ethanol $=1: 3$ ). Mature disc florets removed from the fixed heads were dehydrated in $70 \%$ ethanol for $30 \mathrm{~min}$, then placed in $99 \%$ ethanol for $1 \mathrm{~h}$ before they were treated with $5 \% \mathrm{NaOH}$ overnight. The anther tissue was isolated from the florets on the slide, flooded with $50 \%$ glycerol and a cover slip was applied. Samples were then examined at $100 \times$ (filament collar) and $400 \times$ (endothecial cell wall thickenings) magnification by light microscopy and photographed.

\section{Chromosomal observations}

For chromosome observation of Synotis xinningensis (voucher: Long-yuan Wang \& Ming Tang 123, HAST, IBSC) and S. changiana (voucher: Long-yuan Wang E Ming Tang 111, HAST, IBSC), root tips were pretreated with $0.1 \%$ colchicine for $2.5 \mathrm{~h}$ before being fixed in Carnoy's solution (glacial acetic acid: absolute ethanol = 1: 3 ), then macerated in a 1:1 mixture of $45 \%$ acetic acid and $1 \mathrm{M} \mathrm{HCl}$ at $37^{\circ} \mathrm{C}$ for $45 \mathrm{~min}$, stained and squashed in Carbol fuchsin.

\section{Results and discussion}

\section{Taxonomic treatment}

Synotis xinningensis M. Tang \& Q. E. Yang, sp. nov.TYPE: CHINA. Hunan, Xinning County, Lang Shan, alt. ca. $480 \mathrm{~m}$, open mixed forests, 28 Oct 2011, Long-yuan Wang \& Ming Tang 123 (holotype, IBSC; isotype, HAST). Figures $1 \mathrm{~A}$ and 2.

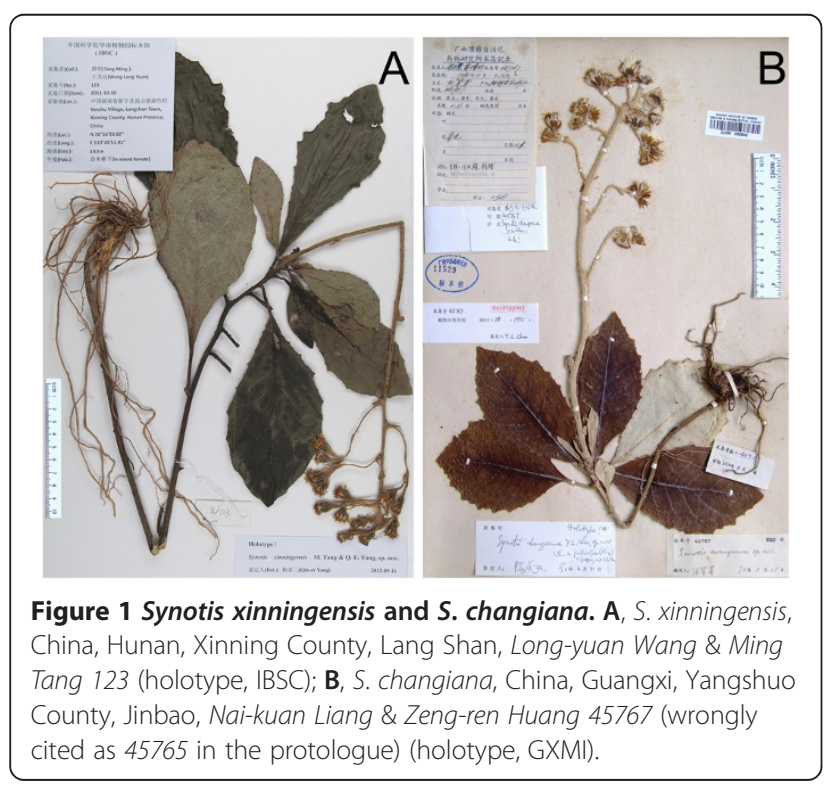

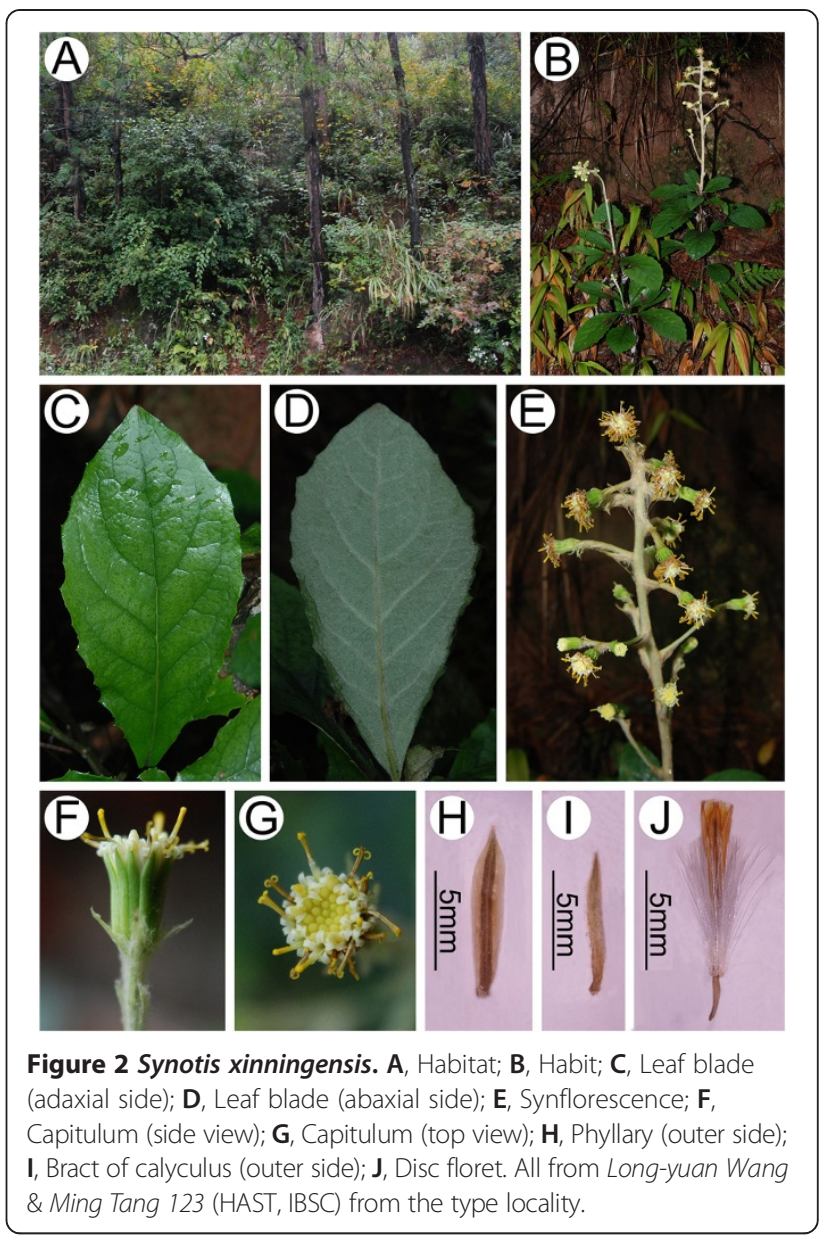

\section{Description}

Herbs, erect, rhizomatous. Rhizome stout, $0.6-1 \mathrm{~cm}$ in diameter. Vegetative stem solitary, 60-85 cm tall, simple, 3-5 $\mathrm{mm}$ in diameter at base, lower part naked, at first arachnoid, more or less glabrescent, upper part fulvous tomentose. Leaves usually densely crowded at middle of stem, rosulate or subrosulate, petiolate; petiole $3.5-4.5 \mathrm{~cm}$ long, stout, densely tomentose; blade obovate-lanceolate, 8-15 cm long, 4.5-8 cm broad, papery, base cuneateattenuate, margin irregularly mucronately sinuate-serrate, apex obtuse to subacute, abaxially densely grayish white arachnoid-tomentose, adaxially dark green, arachnoid, glabrescent, pinnately veined, lateral veins 6-7 pairs, arcuate-ascending. Upper leaves sessile, bract-like, linear. Capitula discoid, 4-21 in terminal corymbs; synflorescence to 1-18 cm long, densely fulvous tomentose, subsessile or short-pedunculate, bracteate at base; bracts linear, 10-13 mm long, acute. Involucres campanulate, 8-10 mm long, 8-12 $\mathrm{mm}$ broad, base fulvous tomentose, calyculate; bracts of calyculus 9-10, 6-7 mm long, linear-subulate, acute; phyllaries 12-13, oblong-lanceolate, 8-10 mm long, 2-2.5 mm broad, herbaceous, glabrous, margin broadly scarious, inconspicuously 3-veined, apically slightly acute 
or obtuse. Ray florets absent. Disc florets many; corolla yellow, 9-11 mm long, tube 3-3.5 mm long, limb narrowly funnelform; lobes oblong-lanceolate, acute. Anthers linear, $3.5-4 \mathrm{~mm}$ long, basally caudate, antheropodia slightly expanded. Style branches recurved, apically obtuse, papillose. Achenes ca. $2 \mathrm{~mm}$ long, glabrous. Pappus white, 6-7 mm long.

\section{Additional specimens examined}

CHINA. HUNAN: Xinning County, Luoyuan, Jigong Shan, in forests at mountaintop, alt. 1000 m, 9 Aug 1985, Yi-bo Luo 3060 (PE); Xinning County, Bajiaozhai, in forests on mountain slopes, alt. 450 m, 13 Sept 1985, Yi-bo Luo 3349 (PE).

\section{Etymology}

The specific epithet 'xinningensis' is derived from the type locality, Xinning County, southwestern Hunan Province, China.

\section{Phenology}

Flowering October; fruiting November.

\section{Distribution and habitat}

Synotis xinningensis is currently known only from Xinning County, southwestern Hunan Province, China (Figure 3). It grows in open mixed forests at $450-1,000 \mathrm{~m}$ above sea level.

\section{Floral micromorphological characters}

As shown in Figure 4A, C, the filament collars of both Synotis xinningensis and S. changiana are balusterform, being basally dilated and consisting of larger cells, conforming to the results reported previously for some other species of Synotis (Jeffrey and Chen 1984). The anther endothecial cell wall thickenings of $S$. xinningensis (Figure 4B) were distributed along all the inner walls of the endothecial cells, and thus were radial. Synotis changiana also had the same pattern of anther endothecial cell wall thickenings (Figure 4D). The observations agree with previous reports for other species of Synotis (Jeffrey and Chen 1984). The floral micromorphological characters indicate that Synotis is a member of subtribe Senecioninae as defined by Nordenstam (2007).

\section{Chromosome cytology}

The metaphase chromosomes of Synotis xinningensis were counted to be $2 n=40+0-1 \mathrm{~B}$ (Figure 5A). According to the chromosome nomenclature of Levan et al. (1964), S. xinningensis had 22 median-centromeric (m), 14 submedian-centromeric $(\mathrm{sm})$ and 4 subterminalcentromeric (st) chromosomes (Figure 5C), i.e. $2 n=$ $40=22 \mathrm{~m}+14 \mathrm{sm}+4 \mathrm{st}$. In the six individuals examined, three were found to have one small B-chromosome in the metaphase cell. The metaphase chromosomes of S. changiana also were counted to be $2 n=40$ (Figure $5 \mathrm{~B}$ ), including $20 \mathrm{~m}, 16 \mathrm{sm}$ and 4 st (Figure 5D), i.e. $2 n=40=$

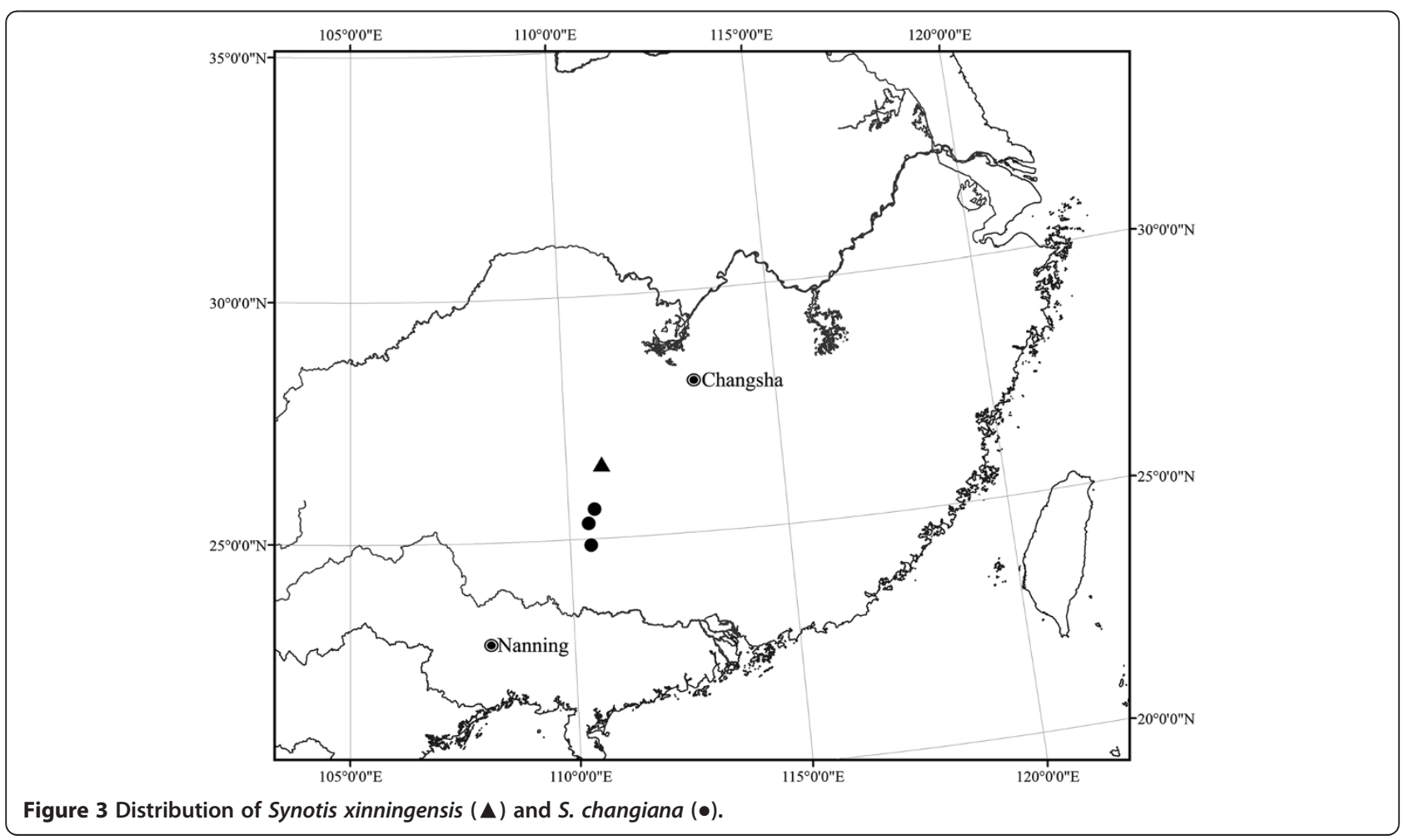




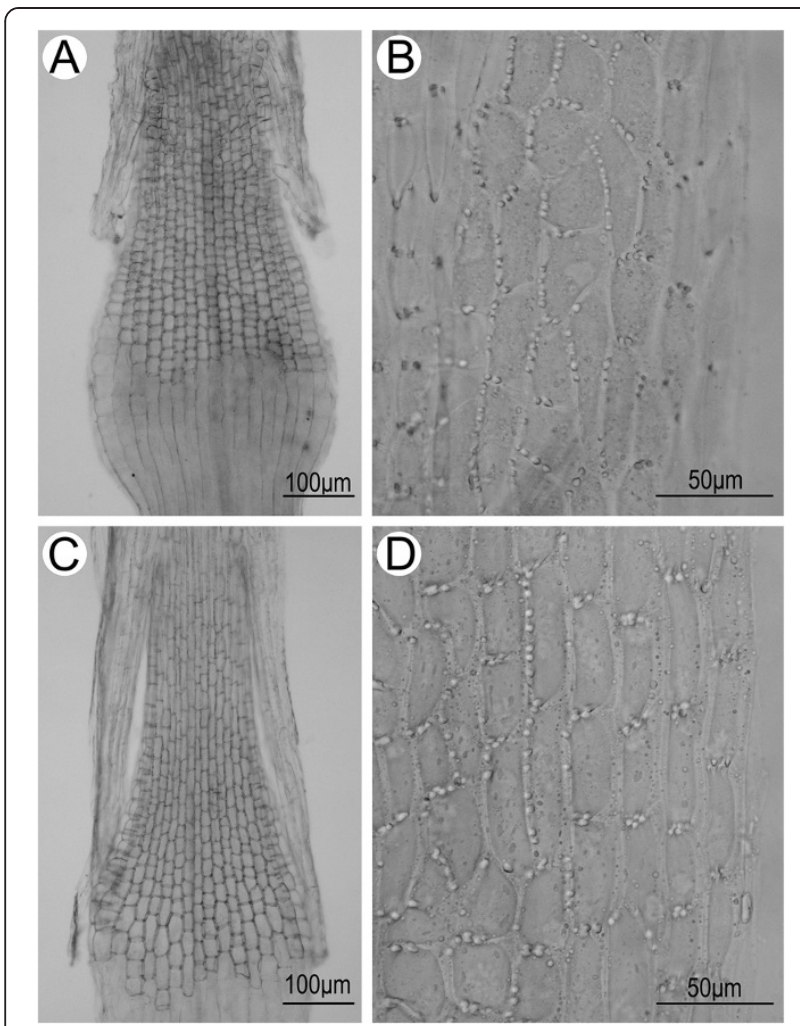

Figure 4 Filament collar $(A, C)$ and anther endothecial cell wall thickenings $(B, D)$ of Synotis xinningensis $(A, B)$ and $S$. changiana (C, D). A and B from Long-yuan Wang \& Ming Tang 123 (HAST, IBSC) from the type locality; C and D from Long-yuan Wang \& Ming Tang 111 (HAST, IBSC) from Xing'an County, Guangxi, China.

$20 m+16 s m+4$ st. No B-chromosomes were observed in this species. In chromosome number and chromosome morphology, Synotis xinningensis is essentially the same as S. changiana.

The genus Synotis is poorly known cytologically, with reports of chromosome numbers for only three species. Synotis alata (Wall. ex DC.) C. Jeffrey \& Y. L. Chen was reported from Indian material, under the name Senecio alatus Wall. ex DC., to have $n=20$ (Mehra et al. 1965). The chromosomes of S. rufinervis (DC.) C. Jeffrey \& Y. L. Chen were reported, also from Indian material and under the name Senecio rufinervis DC., to have $n=18$ (Mehra and Remanandan 1975), $n=10$ (Gupta and Gill 1981, 1989; Gupta et al. 2010), or $n=20$ (Gupta and Gill 1989; Gupta et al. 2010). Liu et al. (2006) mentioned S. lucorum (Franch.) C. Jeffrey \& Y. L. Chen, a plant endemic to northwestern Yunnan, China, to have $2 n=40$. It should be noted that in that paper the plant was stated to have radiate capitula, but S. lucorum actually has discoid capitula (Jeffrey and Chen 1984; Chen 1999), so the material examined may have been misidentified or an error in observation occurred.

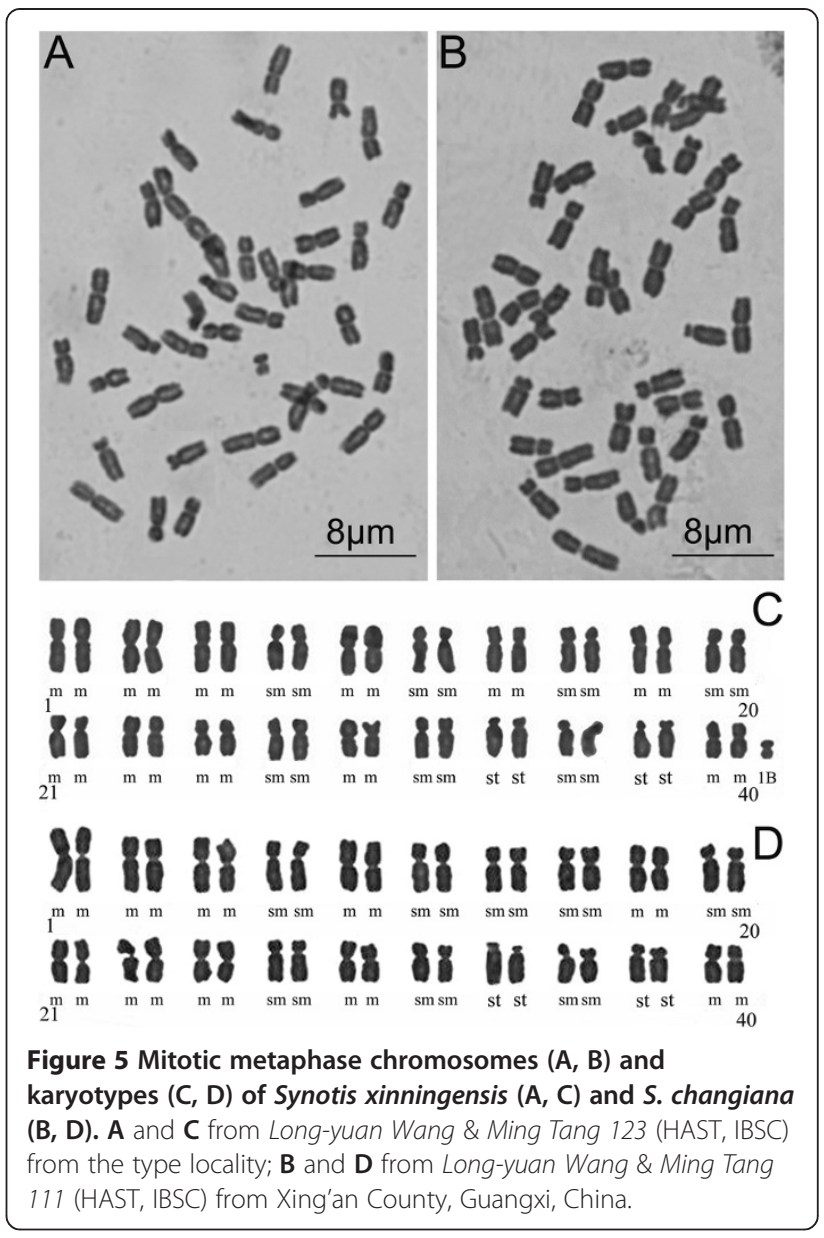

From the very limited chromosome data available, the most reliable basic chromosome number of Synotis appears to be $x=10$, a basic number also characteristic of the genus Senecio L. as re-defined by Pelser et al. (2007). If this inference is correct, then both Synotis xinningensis and its putative closest relative, S. changiana, are tetraploid. More species of Synotis need to be examined cytologically to determine the variation pattern of the chromosomes and its systematic implications for the genus.

\section{Notes}

Synotis xinningensis is most similar to S. changiana (Figure 6), but readily distinguishable in the discoid capitula (vs. radiate) (Figures 1 and 2, 6 and 7), and in the bracts of the calyculus 9-10 (vs. 6-8), 6-7 mm long (vs. 3-4 mm) (Figure 7).

Synotis xinningensis is distributed in southwestern Hunan, and S. changiana in northeastern Guangxi, so their distribution ranges are adjacent to each other, only some $80 \mathrm{~km}$ apart (Figure 3). Both species prefer similar habitats, growing in open mixed forests at elevations between 450 and $1000 \mathrm{~m}$ above sea level. 


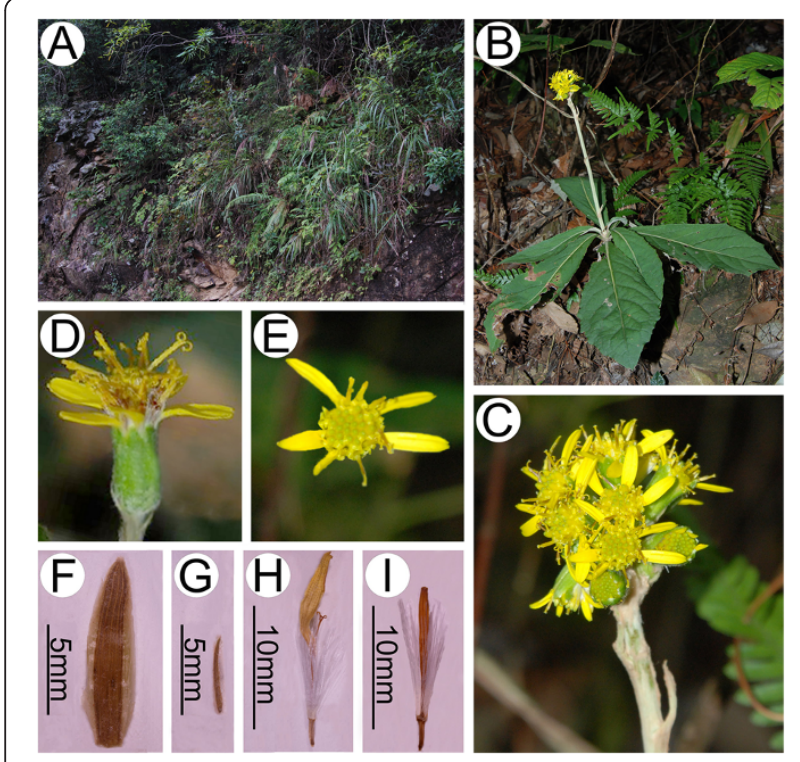

Figure 6 Synotis changiana. A, Habitat; B, Habit; C, Synflorescence; D, Capitulum (side view); E, Capitulum (top view); F, Phyllary; G, Bract of calyculus; H, Ray floret; I, Disc floret. All from Long-yuan Wang \& Ming Tang 111 from Xing'an County, Guangxi, China (HAST, IBSC).

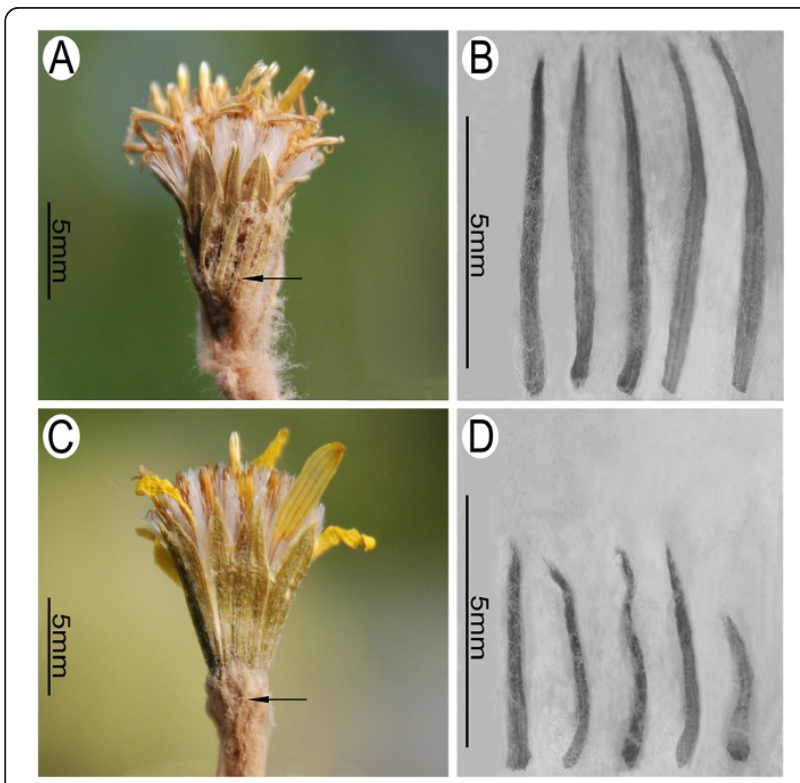

Figure 7 Capitula (A, C) and bracts of calyculus (B, D) in Synotis xinningensis $(A, B)$ and $S$. changiana $(C, D)$, showing differences in length of bracts of calyculus (arrows). A and $\mathbf{B}$ from Long-yuan Wang \& Ming Tang 123 (HAST, IBSC) from the type locality; C and D from Long-yuan Wang \& Ming Tang 111 (HAST, IBSC) from Xing'an County, Guangxi, China.
Jeffrey and Chen (1984), and Chen (1999) divided Synotis into two well-marked sections, sect. Synotis and sect. Atractylidifoliae C. Jeffrey \& Y. L. Chen; all but one of the species (S. atractylidifolia) fall within the former, which itself is divisible into five not very clearly differentiated series. Synotis xinningensis, with its herbaceous leaves rosulate or subrosulate at the base of inflorescence, the lower part of stem leafless at anthesis, and the inflorescence terminal, can be readily referred to ser. Synotis. In addition to S. xinningensis, series Synotis now includes 19 species (Chen et al. 2011; this study). Within series Synotis, only S. xinningensis and S. changiana have leaves that are always abaxially densely gray-white arachnoid-tomentose; all other species of series Synotis have leaves that are abaxially only sparsely arachnoid or puberulent, and often glabrescent (Jeffrey and Chen 1984; Chen 1999; Chen et al. 2011).

\section{Conclusions}

Synotis xinningensis is most similar to S. changiana, but readily distinguishable by having discoid capitula and 9-10 longer bracts of calyculus. Both species belong to Synotis ser. Synotis.

\section{Competing interests}

The authors declare that they have no competing interests.

\section{Authors' contributions}

MT and LYW discovered the new species, and carried out morphological and cytological observations; QEY performed the analyses and drafted the manuscript. All authors read and approved the final manuscript.

\section{Acknowledgements}

We are grateful to Dr. David E. Boufford for his invaluable comments on the manuscript. We thank Mr. Ke-jian Yan, curator of GXMI, for sending us a photograph of the holotype of Synotis changiana. This work was supported by the National Natural Science Foundation of China (grant nos. 31170186 , 30970183), and the Foundation of Key Laboratory of Plant Resources Conservation and Sustainable Utilization, South China Botanical Garden, Chinese Academy of Sciences.

\section{Author details}

${ }^{1}$ Key Laboratory of Plant Resources Conservation and Sustainable Utilization, South China Botanical Garden, Chinese Academy of Sciences, Xingke Road, Tianhe District, Guangzhou 510650, China. ${ }^{2}$ School of Life Science, Sun Yatsen University, Guangzhou 510275, China. ${ }^{3}$ University of Chinese Academy of Sciences, Beijing 100049, China.

Received: 25 October 2012 Accepted: 12 November 2012 Published: 23 August 2013

\section{References}

Chen YL (1995) The new species of the tribe Senecioneae (Compositae) from China. Acta Phytotax Sin 33:76-85

Chen YL (1999) Synotis. In: Chen YL (ed) Flora Reipublicae Popularis Sinicae, tomus 77 (1). Science Press, Beijing, pp 167-217

Chen YL, Nordenstam B, Jeffrey C (2011) Synotis. In: Wu ZY, Raven PH (ed) Flora of China, vol 20-21. Science Press \& Missouri Botanical Garden Press, Beijing \& St. Louis, pp 489-505

Gupta RC, Gill BS (1981) In: Löve Á (ed) IOPB chromosome number reports LXXI. Taxon 30:514

Gupta RC, Gill BS (1989) Cytopalynology of north and central Indian Compositae. J Cytol Genet 24:96-105 
Gupta RC, Bala S, Goyal H, Malik RA, Kumari S (2010) Cytological studies in some members of tribe Senecioneae (Asteraceae) from north and central India. Cytologia 74:369-378

Jeffrey C, Chen YL (1984) Taxonomic studies on the tribe Senecioneae (Compositae) of Eastern Asia. Kew Bull 39:205-446

Levan A, Fredga K, Sandberg AA (1964) Nomenclature for centromeric position on chromosomes. Hereditas 52:201-220

Liu Y, Yang QE (2010) Sinosenecio yilingii (Asteraceae), a new species from Sichuan, China. Bot Stud 51:269-275

Liu Y, Yang QE (2011a) Cytology and its systematic implications in Sinosenecio (Senecioneae-Asteraceae) and two closely related genera. Plant Syst Evol 291:7-24

Liu Y, Yang QE (2011b) Floral micromorphology and its systematic implications in the genus Sinosenecio (Senecioneae-Asteraceae). Plant Syst Evol 291:243-256

Liu Y, Yang QE (2011c) Hainanecio (Asteraceae), a new genus of the Senecioneae, Asteraceae from China. Bot Stud 52:115-120

Liu Y, Yang QE (2011d) Sinosenecio sichuanicus (Asteraceae), a new species from Sichuan, China. Bot Stud 52:219-223

Liu Y, Yang QE (2012) Sinosenecio jiangxiensis (Asteraceae), a new species from Jiangxi, China. Bot Stud 53:401-414

Liu JQ, Wang YJ, Wang AL, Hideaki O, Abbott RJ (2006) Radiation and diversification within the Ligularia-Cremanthodium-Parasenecio complex (Asteraceae) triggered by uplift of the Qinghai-Tibetan Plateau. Mol Phylogenet Evol 38:31-49

Liu Y, Chen GX, Yang QE (2009) Sinosenecio baojingensis (Asteraceae), a new species from Hunan, China. Bot Stud 50:107-113

Liu Y, Zhang DG, Yang QE (2010) Sinosenecio hupingshanensis (Asteraceae), a new species from Hunan and Hubei, China. Bot Stud 51:387-394

Liu ZY, Liu Y, Yang QE (2011) Sinosenecio nanchuanicus (Asteraceae), a new species small in size yet high in chromosome number from Chongqing, China. Bot Stud 52:105-113

Mehra PN, Remanandan P (1975) Cytological investigations on the Indian Compositae. IV. Tribes Senecioneae, Eupatorieae, Vernonieae and Inuleae. Nucleus 18:6-19

Mehra PN, Gill BS, Mehta JK, Sidhu SS (1965) Cytological investigations on the Indian Compositae. I. North-India taxa. Caryologia 18:35-68

Nordenstam B (2007) Tribe Senecioneae. In: Kadereit JW, Jeffrey C (ed) The Families and Genera of Vascular Plants, vol VIII. Springer, Berlin and Heidenberg, pp 208-241

Nordenstam B, Pelser PB (2011) Notes on the generic limits of Sinosenecio and Tephroseris (Compositae-Senecioneae). Comp Newsl 49:1-7

Pelser PB, Nordenstam B, Kadereit JW, Watson LE (2007) An ITS phylogeny of tribe Senecioneae (Asteraceae) and a new delimitation of Senecio L. Taxon 56:1077-1104

Zhang DG, Liu Y, Yang QE (2008) Sinosenecio jishouensis (Compositae), a new species from north-west Hunan, China. Bot Stud 49:287-294

doi:10.1186/1999-3110-54-16

Cite this article as: Tang et al:: Synotis xinningensis (Asteraceae), a new species from Hunan, China. Botanical Studies 2013 54:16.

\section{Submit your manuscript to a SpringerOpen ${ }^{\circ}$ journal and benefit from:}

- Convenient online submission

- Rigorous peer review

- Immediate publication on acceptance

- Open access: articles freely available online

- High visibility within the field

- Retaining the copyright to your article

Submit your next manuscript at $\gg$ springeropen.com 